\title{
ORF VIRUS INFECTION IN WILD GOATS (CAPRA AEGAGRUS ERXLEBEN 1777) OF SARICICEK MOUNTAIN
}

\author{
GÜNDOĞDU, E.* - ARPACIK, A. - SARI, A. - BAŞKAYA, Ş. \\ Department of Wildlife Ecology and Management, Faculty of Forestry, Karadeniz Technical \\ University, Trabzon, Turkey \\ (phone: +90-505-934-3200) \\ *Corresponding author \\ e-mail: ebubekirgundogdu@gmail.com \\ (Received $22^{\text {nd }}$ May 2018; accepted $5^{\text {th }}$ Jul 2018)
}

\begin{abstract}
Orf virus occurs where sheep and goats are raised, and it also infects a broad range of wild artiodactyls. The rates of morbidity and mortality are higher, particularly in lambs and kids experiencing the disease for the first time. Orf virus has been reported in domestic animals and humans in Turkey, so far. In this study, findings on the presence of Orf virus on wild goats were researched for the first time. Field studies were carried out between 2016 and 2017 years. Direct observation methods were used in field studies. In this study, a dead six months of age male wild goat (Capra aegagrus) and 3 diseased individuals in poor condition with bloody lesions covering the muzzle area were examined in Sarıçiçek Mountain in Eastern Black Sea Region, Turkey. The gross and microscopic lesions confirmed the diagnosis of contagious ecthyma (CE). This is the first documented report of CE in wild goat from Turkey.
\end{abstract}

Keywords: contagious ecthyma, bezoar goat, skin lesions, disease, Turkey

\section{Introduction}

Contagious ecthyma is a parapox virus which affects domestic sheep and goats around the world (Samuel et al., 1975; Yirrell et al., 1989; Wilson and McFarlane, 2012; Peralta et al., 2018; Tedla et al., 2018). It is characterized to have a benign nature, and it can cause a large tumor like vascularized lesions which can be treated using antiviral drugs or removed surgically. It is transmitted through direct contact with infected animals and environmental contamination (Tedla et al., 2018). CE is also a zoonosis of global distribution that affects humans, particularly animal workers, like slaughtermen, veterinarians, farmers, and animal caretakers, after direct or indirect contact with infected animals (Peralta et al., 2018). It has a linear double-stranded DNA genome, of $\sim 135 \mathrm{kbp}$ in size and exhibits an unusually high GC content $(\sim 64 \%)$. The central region of the genome contains 88 genes which are present in the subfamily Chordopoxvirinae and mostly occur in a common order and orientation. The terminal regions of the genome are variable and there are genes associated with virulence, pathogenesis, tropism, and/or immune response modulators (Fleming and Mercer, 2007; Lateef et al., 2010; Peralta et al., 2018). Clinical CE is generally named as contagious pustular dermatitis, orf, soremouth, or scabby mouth. The illness leads to pustules followed by scabbing on the muzzle, face, and lips of ruminants (Wilson and McFarlane, 2012; Tedla et al., 2018). Mortality and morbidity is changeable (Housawi et al., 1992; Elzein and Hausawi, 1997; Haig and Mercer, 1998; Nandi et al., 2011; McInnes, 2014). The reason of CE is Orf virus which is type species of the genus Parapoxvirus (Webster, 1958; Delhon et al., 2004; Mercer et al., 2006; McGuire et al., 2012; Li et al., 2012). The virus in dried scabs survived from 8 months to more than a 
year at room temperature (Manley, 1934; Newsom and Cross, 1934). Crusts exposed to external conditions lost their infectivity quickly during summer, but infectivity persisted for at least 6 months during winter (Boughton and Hardy, 1935). The disease may be caused by direct or indirect contact with the infected animals especially with dried crusts fallen on the pastures during grazing (Harriss, 1948; Kummeneje and Krogsrud, 1979). The disease was also transmitted from wild to domestic goats when infected herds had prolonged contact with salt blocks in the mutual habitat. The disease from infected sheep and goats has been transmitted to other species of animals by feeding them raw sheep carcasses (Wilkinson et al., 1970). Contagious pustular dermatitis of sheep and goats was reported initially by Zellor in 1920 from South West Africa. Since then, it has been reported from almost all parts of world involving not only sheep and goats but cattle, dogs, camel and both free living wild and captive animals also. Lesions can also form inside the mouth, on the coronary band above the hooves, on the udder, or on the genitalia. The incubation period from exposure to the virus until development of clinical signs is 1 to 2 weeks (Merck Veterinary Manual, 2016). CE is not usually lethal, and lesions typically disappear within 2 to 4 weeks, but death may occur if secondary complications, such as bacterial infections or myiasis, develop. Additionally, lesions can be quite painful and hinder feeding in adults or nursing in lambs and kids, leading to emaciation and death, depending on the severity of the infection (Davis et al., 1970). CE is infectious to humans and is considered an occupational hazard for shepherds, with lesions typically found on the hands as a result of direct contact with animal lesions (Uzel et al., 2005; CDCP, 2006). However, not all CE cases in humans are confined to those in contact with sheep or goats (Ballanger, 2006). CE viruses spread from one region to other region which has been occurred by free movements of animals (Mayenga, 2015). The diagnosis of CPD is mainly based on benign nature of the disease and characteristic skin lesions (Rodrignez et al., 1983; Coates and Hoff, 1990). Vaccination coupled with biosecurity measures is an effective method in the prevention and control of CE. Suspected CE can be diagnosed based on the characteristic clinical signs, followed by laboratory tests such as electron microscopy, serum neutralization tests (SNT), histopathology of affected tissues and nucleic acid assay like polymerase chain reaction (PCR) (Nandi et al., 2011; Adeleji et al., 2018).

\section{Materials and methods}

Sarıçiçek Mountain is located within the borders of Şebinkarahisar and Çamoluk districts $\left(40^{\circ} 19^{\prime} 50.18^{\prime \prime} \mathrm{N} 38^{\circ} 29^{\prime} 55.53^{\prime \prime}\right.$ E) in Giresun province part of Eastern Black Sea Region (Fig. 1). The study area is 21765 ha and between 1000 and $1800 \mathrm{~m}$ elevations on average. On majority of lands of Sarıçiçek Mountain, the dominant climate is continental. Winters are long and harsh, and summers short and hot. Annual mean temperature is between -15 and $+32{ }^{\circ} \mathrm{C}$. Annual mean precipitation is between 500 and $700 \mathrm{~mm}$. Pine (Pinus sylvestris) and oak (Quercus sp.) forests and alpine steppes have a wide spread in the study area. The study area is one of the most important habitats of about 1500 wild goat in the Eastern Black Sea Region.

This study started as a result of reporting the Orf virus symptoms in wild goat individual by wildlife officers in Sarıçiçek Mountain, on February, 2016. Field studies were carried out between 2016 and 2017 years. Direct observation methods were used in the field studies. Camera traps, binoculars and spotting scopes were utilized along with direct observation. Camera trapping was applied to the wild goat population 
density areas during the study period in order to determine diseased wild goats. Also, we investigated the carcasses of wild goats perished due to $\mathrm{CE}$ in the study area.

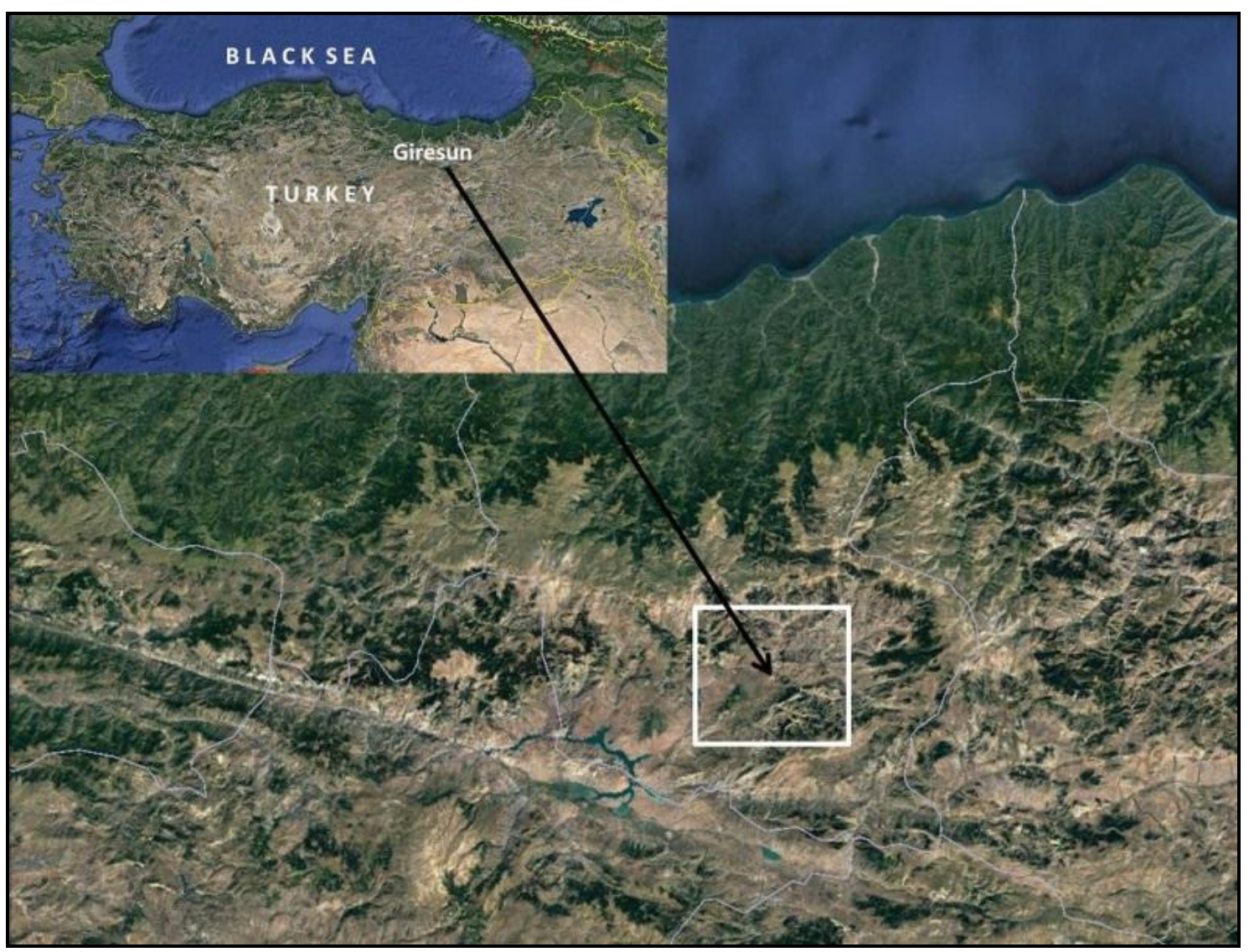

Figure 1. Location of the study area (GoogleEarth, 2018)

\section{Results and discussion}

As a result of this study, one wild goat individual observed ulcerated papular lesions, including frank red blood on the lips and muzzle with marked swelling and crusting around all edges of the lesions (Fig. 2). Histopathological sections were made of the junction between normal skin and the lesions on the lips and muzzle. The remainders of the carcasses were removed from the research area and were buried.

At the end of the study, 442 camera-trap photos belonging to wild goats were obtained and on two wild goat individuals were observed with ulcerated papular lesions, including frank red blood on the lips and muzzle with marked swelling and crusting around all edges of the lesions. Also a dead wild goat was found. This carcass were removed from the research area and were buried (Fig. 2).

Skin lesions of the dead lambs were determined as characteristic CE lesions (poor body condition with bloody lesions covering the muzzle area and warts in the mouth periphery) in our observations. Typical CE viral particles were seen by electron microscopy. Sections of haired skin from the sample had diffuse acanthosis and hyperkeratosis, with numerous intracorneal vesicles and pustules. Moderate numbers of bacterial colonies were observed among superficial keratinized epithelial cells. There was multifocal intracellular edema of keratinocytes of the stratum spinosum. The 
superficial dermis was infiltrated with numerous lymphocytes, plasma cells, neutrophils, and macrophages. The history, gross lesions, and microscopic lesions histopathologically confirmed the diagnosis of CE. The lesions were considered pathognomonic, based on the findings reported literature (Ishii, 1953; Merwin and Brundige, 1982; Housawi et al., 2012).

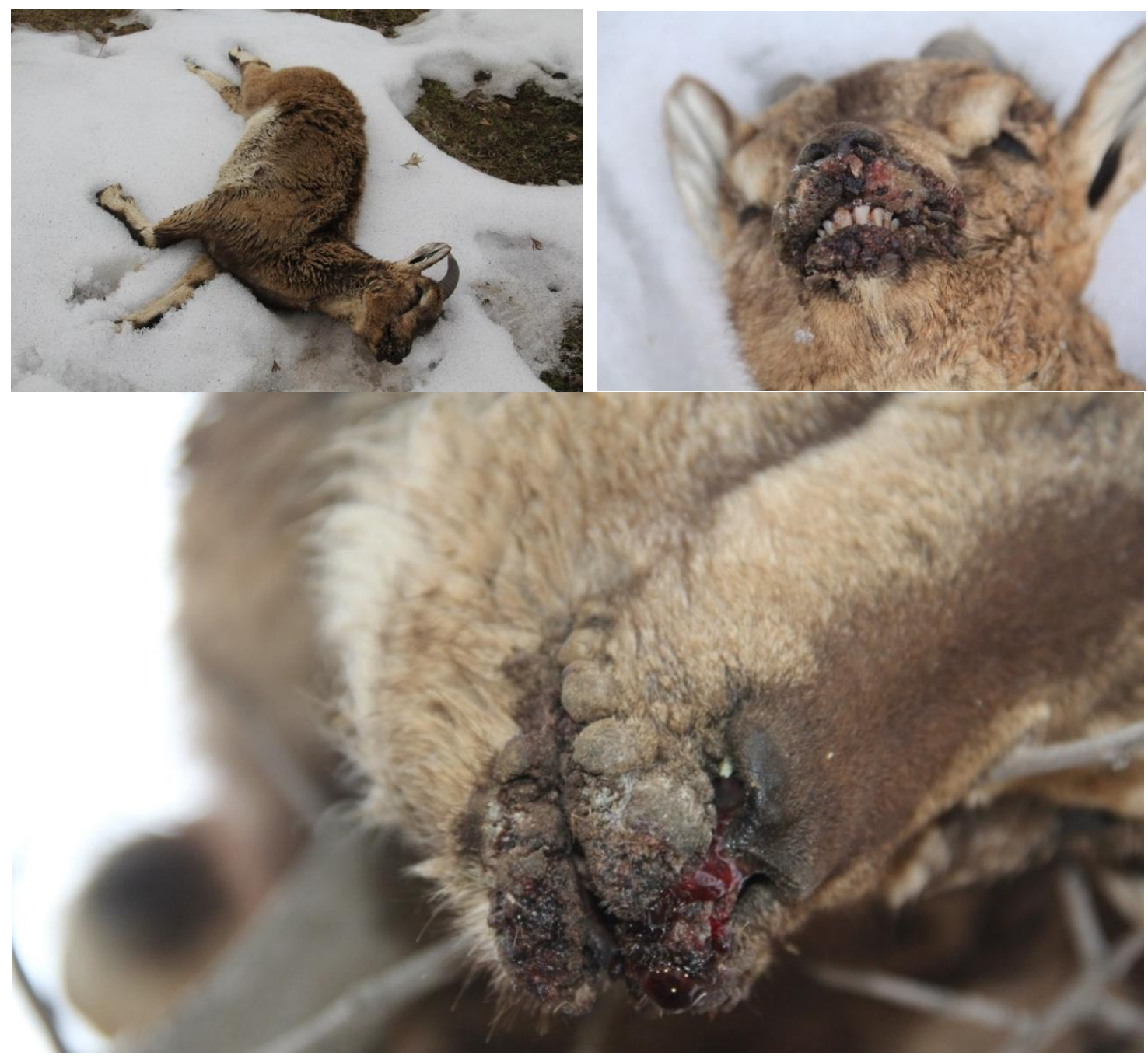

Figure 2. Orf virus infection is evident on the muzzle of wild goat in Sarlçiçek Mountain

It has been reported that lambs may suffer the most from CE infections (Blood, 1971; Samuel et al., 1975; Lance et al., 1981; Merwin and Brundige, 1982; Zarnke et al., 1983) and no signs of CE were reported in previous observations and counts of lambs in Sarıçiçek Mountain. Because this report represents the first documented case of CE about wild goat in Turkey, it is unknown whether the previous low lamb production in this population may have been associated with CE. It is unlikely that the original population was the source of this outbreak of CE, given the short incubation period of 1 to 2 weeks for orf (Merck Veterinary Manual, 2006) and that no diagnoses of CE were made and no clinical signs of orf were reported by wildlife officers or the public for 30 years. It also has been reported that CE may be an important factor for mountain goat 
known to be infected with high numbers of helminths, bacterial infections, or to be in states of poor nutrition (Samuel et al., 1975).

\section{Conclusion}

The studies on CE in Turkey are mainly case reports in the form of single or small groups reported in humans and domestic animals. There is no information about the presence of Orf virus in wild goats due to limited studies about wild animal diseases in Turkey.

The Orf virus is an important contagious disease that can lead to outbreaks and deaths, especially in young and low-immune wild goats. For this reason, detection, isolation, vaccination and separation of wild goats, which are the source of infection, will prevent both new cases and economic losses.

The study area is one of the most important wild goat hunting tourism areas in Turkey. The area is also used extensively by the villagers and shepherds. As the disease is transmitted from infected animals, products or contaminating materials, people who are in contact with these animals or products should be informed about the personal preventive measures. Also, identifying infectious diseases and vaccinations of diseased animals will prevent the spread of the disease.

Acknowledgements. As authors, we would like to thank Giresun, Şebinkarahisar wildlife officers (General Directorate of Nature Conservation and National Parks) for their information and assistance.

\section{REFERENCES}

[1] Adedeji, A. J., Adole, J. A., Chima, N. C., Maguda, A. S., Dyek, D. Y., Jambol, A. R., Anefu, E. O., Shallmizhili, J. J., Luka, P. D. (2018): Contagious ecthyma in three flocks of goats in Jos-south LGA, Plateau State, Nigeria. - Sokoto Journal of Veterinary Sciences 16: 1 .

[2] Ballanger, F., Barbarot, S., Mollat, C., Bossard, C., Cassagnau, E., Renac, F., Stalder, J. F. (2006): Two giant orf lesions in a heart/lung transplant patient. - European Journal of Dermatology 16: 284-286.

[3] Blood, D. A. (1971): Contagious ecthyma in Rocky mountain bighorn sheep. - J. Wildlife Manag. 35: 270-275.

[4] Boughton, I. B., Hardy, W. T. (1935): Immunization of sheep and goats against sore mouth (contagious ecthyma). - Bullet. Texas Agric. Exp. Station 504: 16.

[5] CDCP (2006): Orf virus infection in humans-New York, Illinois, California, and Tennessee, 2004-2005. - Centers for Disease Control and Prevention Morbidity Mortality Weekly Reports 555: 65-68.

[6] Coates, J. W., Hoff, S. (1990): Contagious ecthyma: an unusual distribution of lesions in goats. - Canadian Vet. J. 31: 209-210.

[7] Davis, J. W., Karstad, L. H., Trainer, D. O. (1970): Infectious Diseases of Wild Mammals. - Iowa State University Press, Ames, Iowa, USA.

[8] Delhon G, Tulman, E. R., Afonso, C. L., Lu, Z, de la Concha-Bermejillo, A., Lehmkuhl, H. D., Piccone, M. E., Kutish, G. F., Rock, D. L. (2004): Genomes of the parapoxviruses ORF virus and bovine papular stomatitis virus. - J Virol. 78: 168-177.

[9] Elzein, E. M., Housawi, F. M. T. (1997): Severe long lasting contagious ecthyma infection in a kid. - J. Vet. Med. B 44: 561-564. 
[10] Fleming, S. B., Mercer, A. A. (2007): "Genus Parapoxvirus" in Parapoxviruses. Birkauser, Berlin.

[11] GoogleEarth (2018): https://www.google.com.tr/intl/tr/earth/. - Google, Mountain View, CA.

[12] Haig, D. M., Mercer, A. A. (1998): Ovine diseases. - Orf. Vet. Res. 29: 311-326.

[13] Harriss, S. T. (1948): Proliferative dermatitis of the legs (straberry foot rot) in sheep. - J. Comp. Pathol. 58: 814-828.

[14] Housawi, F. M. T., Abu-Elzein, E. M. E., Al-Afaleq, A. I., Amin, M. M. (1992): Serosurveillance for orf antibodies in sheep and goats in Saudi Arabia employing the ELISA technique. - J. Comp. Pathol. 106: 153-158.

[15] Housawi, F. M., Abuelzein, E. M., Gamee, A. A., Alafaleq, A. I. (2012): Comparative study on three locally developed live orf virüs vaccines for sheep in Saudi Arabia. Onderstepoort J. Vet. Res. 79(1): E1-E5.

[16] Ishii, S., Kawakami, Y., Fukuhara, S. (1953): Pustular dermatitis of sheep and goats. -1. The property of the comparative agent. Exptl. Report. Govt. Exp. Station Anim. Hyg. 27: 141-150.

[17] Kummeneje, K., Krogsrud, J. (1979): Contagious ecthyma (orf) in reindeer (Rangiter tarandus). - Vet. Rec. 105: 60-61.

[18] Lance, W., Adrian, W., Widhalm, B. (1981): An epizootic of contagious ecthyma in Rocky Mountain bighorn sheep in Colorado. - Journal of Wildlife Diseases 17: 601-603.

[19] Lateef, Z., Baird, M. A., Wise, L. M., Young, S., Mercer, A. A., Fleming, S. B. (2010): The chemokine-binding protein encoded by the poxvirus Orf virus inhibits recruitment of dendritic cells to sites of skin inflammation and migration to peripheral lymph nodes. Cell Microbiol. 12: 665-76.

[20] Li, W., Ning, Z., Hao, W., Song, D., Gao, F., Zhao, K., Liao, X., Li, M., Rock, D. L., Luo, S. (2012): Isolation and phylogenetic analysis of orf virus from the sheep herd outbreak in northeast China. - BMC Veterinary Research 8: 229.

[21] Manley, F. H. (1934): Observations on the virus of contagious pustular dermatitis. - Vet J. 90: 80-91.

[22] Mayenga, C. (2015): Molecular diagnosis and characterisation of orf virus in symptomatic goats in coast and Dar Es Salaam regions, Tanzania. - A dissertation submitted in partial fulfilment of the requirements for the degree of Master of Science in health molecular biology of Sokoine University of Agriculture, Morogoro, Tanzania.

[23] McGuire, M. J., Johnston, S. A., Sykes, K. F. (2012): Novel immunemodulator identified by a rapid, functional screen of the parapoxvirus ovis (Orf virus) genome. - Proteome Sci. 10:4.

[24] McInnes, C. J. (2014): Orf. - Vet. Dermatol. 25(4): 341-342.

[25] Mercer, A. A., Ueda, N., Friederichs, S. M., Hofmann, K., Fraser, K. M., Bateman, T., Fleming, S. B. (2006): Comparative analysis of genome sequences of three isolates of Orf virus reveals unexpected sequence variation. - Virus Res. 116: 146-158.

[26] Merck Veterinary Manual (2006): Contagious Ecthyma. - Merck and Company Inc., Whitehouse Station, New Jersey, USA.

[27] Merwin, D. S., Brundige, G. C. (1982): An unusual contagious ecthyma outbreak in Rocky Mountain bighorn sheep. - Biennial Symposium Northern Wild Sheep and Goat Council 12: 75-82.

[28] Nandi, S., De, U. K., Choudhary, S. (2011): Current status of contagious ecthyma or orf disease in goat and sheep - a global perspective. - Small Rum. Res. 96: 73-82.

[29] Newsom, I. E., Cross, F. (1934): Sore mouth in feeder lambs due to a filterable virus. - J. Am. Vet. Med. Assoc. 84: 231-247.

[30] Peralta, A., Robles, C. A., Micheluod, J. F., Rossanigo, C. E., Martinez, A., Carosio, A., König, G. A. (2018): Phylogenetic analysis of ORF viruses from five contagious ecthyma outbreaks in Argentinean goats. - Front. Vet. Sci. 5: 134. 
[31] Rodrignez, B., Correa-Giron, P., Trigo, F., Hernahdez, J. P. (1983): Contagious ecthyma of sheep in Mexico. - Proceedings of the Annual Meeting of the American Assoc. Vet. Lab. Diag. 23: 225-235.

[32] Samuel, W. M., Chalmers, G. A., Stelfox, J. G., Loewen, A., Thomsen, J. J. (1975): Contagious ecthyma in bighorn sheep and mountain goat in Western Canada. - Journal of Wildlife Diseases 11: 26-31.

[33] Tedla, M., Berhan, N., Molla, W., Temesgen, W., Alemu, S. (2018): Molecular identification and investigations of contagious ecthyma (Orf virus) in small ruminants, Northwest Ethiopia. - BMC Veterinary Research 14: 13

[34] Uzel, M., Sasmaz, S., Bakaris, S., Cetinus, E., Bilgic, E., Karaoguz, A., Ozkul, A., Arican, O. (2005): A viral infection of the hand commonly seen after the feast of sacrifice: human orf (orf of the hand). - Epidemiology of Infections 133: 653-657.

[35] Webster, R. G. (1958): The immunological relations of the contagious pustular virus to the mammalian pox group. - Aust. J. Experim. Biol. Med. Sci. 36: 267-274.

[36] Wilkinson, G. T., Prydie, J., Scarnell, J. (1970): Possible 'orf' (contagious pustular dermatitis, contagious ecthyma of sheep) infection in the dog. - Vet. Rec. 87: 766-767.

[37] Wilson, D. J., Mc Farlane, L. (2012): Contagious ecthyma in a Rocky Mountain bighorn sheep from Utah. - Human-Wildlife Interactions 6(1): 7-11.

[38] Yirrell, D., Reid, H. W., Norval, M., Howie, S. E. M. (1989): Immune response of lambs to experimental infection with orf virus. - Vet. Immunol. Immunopathol. 22: 321-332.

[39] Zarnke, R. L., Dieterich, R. A., Neiland, K. A., Ranglack, G. (1983): Serologic and experimental investigations of contagious ecthyma in Alaska. - Journal of Wildlife Diseases 19: 170-174. 